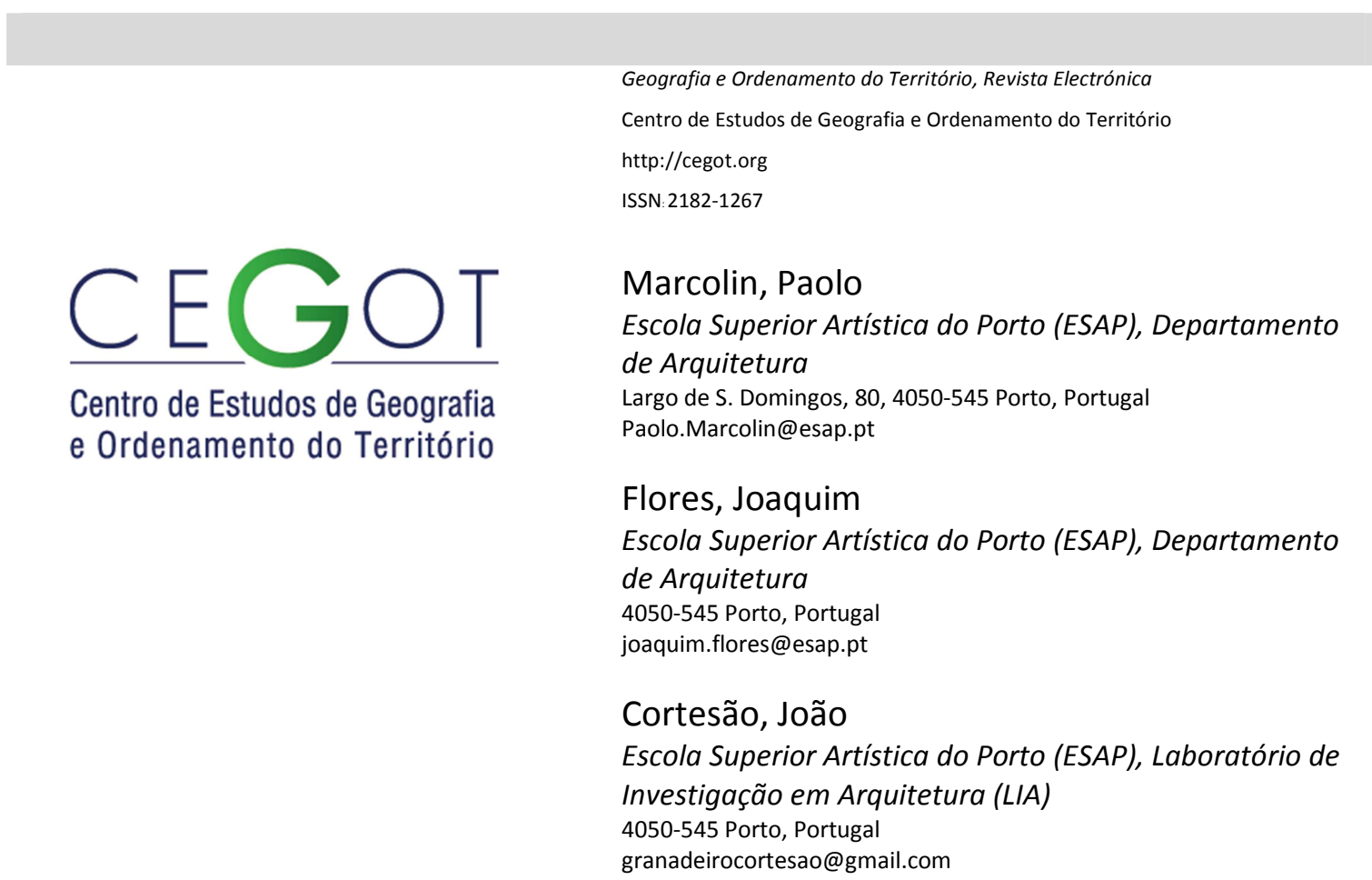

\title{
Outline for a human-based assessment methodology of urban projects. The case of Polis Gondomar
}

Referência: Marcolin, Paolo et al. (2015). Outline for a human-based assessment methodology of urban projects. The case of Polis Gondomar. (GOT), n. 7 (junho). Centro de Estudos de Geografia e Ordenamento do Território, p. 183-211, dx.doi.org/10.17127/got/2015.7.008

\section{Resumo}

Neste artigo apresenta-se uma síntese dos resultados da primeira fase de um projeto de investigação referente à construção de uma metodologia de avaliação de impactes do(s) projeto(s) urbano(s) no desenvolvimento da cidade ${ }^{1}$. Nesta fase, a investigação centrou-se na identificação de indicadores sobre o êxito do projeto urbano do ponto de vista da finalização, funcionamento e utilização dos espaços e serviços de uso público, tendo como caso de estudo a intervenção realizada no âmbito do Programa Polis em Gondomar.

Palavras-Chave: Projeto Urbano; indicadores de avaliação de impactes, uso e conforto em espaços públicos, benefícios e valores económicos.

\section{Abstract}

This paper presents the results of a preliminary research project proposing an assessment

\footnotetext{
${ }^{1}$ Projeto de investigação inserido nos Projetos ESAP 2013, intitulado "Referências de base para a elaboração de uma metodologia de avaliação dos impactes de projetos urbanos no desenvolvimento da cidade" e com a referência ESAP/2013/P01/DARQ.
} 
methodology for the actual impacts of urban projects on city development ${ }^{2}$. At this stage, the research has focused on the identification of indicators about the success of urban projects according to the accomplishment, functioning and use of public spaces. A case study is presented as a means for exploring these indicators: the intervention made by the Polis Programme at Gondomar.

Keywords: Urban Project; impact assessment indicators; use and outdoor comfort; benefits and economic values.

\section{Introduction}

Since the 60s, in the European context, the use of the urban project figure as practice and privileged instrument of urban intervention has been given a growing importance. From services and infrastructures over urban areas in the need of requalification, to urban areas with the potential for transforming/expanding the traditional city or for restructuring emergent agglomerations, the urban project is regarded as an instrument with the potential to create urban fabrics and environments rich in new formal and functional complexities. In Portugal, likewise other European countries, the emergent practices are related to the concept of urban project as a means of transferring knowledge and the purposes of urban policies into real actions. This can be put into practice, be implemented and regulated through formal planning figures or contracting models. Some studies made on different urban project experiences in Portugal (such as Portas and Cabral, 2011; Pelucca, 2010; Ferretti, 2012) however confirm that, in the national context, there is still a lack of systematization of the reasons and arguments that allow accordingly assess the success and the actual effects of these experiences (Portas and Cabral, 2011) $)^{3}$. Eventually it was defined as main objective of this research project the identification of some base references able of contributing to the definition of an impact assessment methodology for urban projects. It is therefore aimed for this methodology to be further developed and consolidated in different research stages subsequent to the present research, introducing new evaluation

\footnotetext{
${ }^{2}$ Research project framed by Projetos ESAP 2013, entitled "Referências de base para a elaboração de uma metodologia de avaliação dos impactes de projetos urbanos no desenvolvimento da cidade" with the reference ESAP/2013/P01/DARQ.

${ }^{3}$ Is possible to point the recent cases of the operations Parcerias para a Regeneração Urbana (PRU) undertaken in the cities of Guimarães and Viseu inserted in the programme Política de Cidades POLIS XXI. Accordingly with the report submitted to the Directorate-General for Regional Policy of the European Union (Annex One: Case Studies), these interventions do not present any assessment strategy (ECORYS, 2011).
} 
components and counting on the deepening and refinement of its premises and results. The herewith presented research has therefore a preliminary and exploratory character. It was aimed to identify and test parameters and indicators targeted at the evaluation of aspects related, foremost, to the level of urbanity (Ferretti, 2012) ${ }^{4}$ or the "urban effects" produced by an urban project. It is aimed to launch the base for a tool allowing assessing what an urban project has actually delivered to the site and its surrounding areas ${ }^{5}$ after its establishment and use. The pertinence of this operation is related not only to the need of developing a preliminary study to a fully structured and comprehensive methodology.

The consideration of such a methodology is growingly a need in urban development policies since the 'urban project' action is expected to be generalized (Portas and Cabral, 2011) due to a faster and faster territory transformation rhythm. In Portugal this generalization has already taken place through a number of actions such as Lisbon's Expo'98 precinct or those framed by the Polis (e.g. Viana do Castelo, Porto, Vila Nova de Gaia, Coimbra, Leiria, Lisboa or Albufeira) and Polis XXI Programmes, which gave a new shape and life to many urban centres in the country since the early 2000s. The instruments brought by the Polis XXI Programme suppressed the weaknesses of the precedent Polis Programme such as the engagement of different parties involved in planning (MAOTDR) ${ }^{6}$.

The Polis XXI Programme came to confirm the need for fostering interventions able of reinvigorating urban centres. According to the analysis presented in the Abordagens Integradas de Base Territorial: Relatório final (OQ, 2010, p.31) is possible to find a substantial difference between the PRU applications and the targets established for 2015. Further, it is stated that this situation aggravated with the release of additional

\footnotetext{
${ }^{4}$ Ferretti's ideia of urbanity was considered here because it could synthesize in a plain way the basal qualitative aspects of urban projects. Ferretti assumes that one of the imperative conditions for assessing the quality of a built space through the urban project is linked to the degree of urbanity. To define this term, this author, supported in important conceptual references (Lynch, 2006; Marinoni, 2005; Majoor, 2008; Perec, 1989) gathers and correlates an group of concepts that characterize the most dynamic, attractive and efficient urban environments, accounting with multiple diversities delivering them some polarization capacity. These effects integrate distinct aspects or qualities, but that end up being concurrent to the quality and identity of the humanized spaces, such as for instance, vitality and accessibility, density as capacity for concentrating opportunities and cultural values, multiplicity and diversity of the physical and evocative spaces, higher level of delivery and efficiency of services.

${ }^{5}$ The production of effects that are extended beyond the respective intervention area is one of the first five points for the definition of urban project by Manuel de Solá Morales, and constitutes an important reference about the capacity of urban projects to contribute to city and territory development.

${ }^{6}$ The Polis XXI Programme policies encompassed four instruments: urban regeneration partnerships (PRU), urban networks for competitiveness and innovation, innovative actions for urban development and anchor facilities for the national urban system.
} 
competitions, revealing a generalization of this programme which contradicts the selectivity assumed in the initial document of the Política de Cidades POLIS XXI.

In the first stage of this research, it was opted to focus in areas that could provide indicators and answers about the success of urban projects. The literature reviewed pointed that the impact of urban projects is usually performed through an ex-ante approach aiming to assess the impact of a project, which is based on the Environmental Impact Assessment (EIA) methodologies (Morris and Therivel, 2009).

It is possible to conclude that the existing and usually used methods are mainly directed to build scenarios in the design stage and to assess the future impacts. In parallel, the majority is focused on urban sustainability issues, in special with the environmental field (Amado, 2012; Partidário, 2007). In the present research project the objective is to measure the impacts of built urban projects under the perspective of how the users feel on the new space. Moreover, the fundamental objectives of the research also cover the global economic and social impacts of the urban project on the surrounding area. Therefore, the focus is set on the user and not in the designer of the urban space, enriching the ante approach, but acting mainly in the post stage.

Thus, it was possible to perceive that the use of 'Key Performance Indicators' (KPI), usually applied in other disciplines rather than urban design, could be more effective than the use of the traditional methods. Even if its objective is to monitor the structure supporting the commercial activities in the urban centre, the focus is put on the data acquisition which may support the definition of management strategies (Hogg et al., 2001). This method is based on the "marketing places» tools which focus on the survey of the «customer» satisfaction (i.e. the user of the urban space) as the core of the monitoring process. Even if this perspective is not entirely coincident with the current research project, it presents a similar objective of identifying and understanding the urban dynamics provoked by any kind of urban intervention, focusing in the user of the public space rather than its designer. As stated by Carlos Balsas (2004) this approach aims to measure the "livability» of the urban centre, defined as the way a urban area succeeds on attracting investment to maintain the viability of its urban functions and quality of life. So, it is possible to establish a relation between this concept and the notion of «urbanity» previously mentioned (Ferretti, 2012: 70).

The subjects related to the implementation and maintenance processes are left to ulterior stages of this research. Based on thermal comfort, socioeconomic benefits, and usage of public spaces and facilities, three experimental systems of indicators were defined: usage, 
comfort and economic values. The consideration of these systems was focused in an area where the intervention was conceived and built framed by the Polis Programme in Gondomar. This is a site within a somewhat problematic context from the viewpoint of urban development and planning. For this reason, it seemed particularly interesting to be used as a stage for evaluating the aforementioned aspects. The following sections, after a brief characterization of the intervention area and of the programmatic aspects, will present the methods and the results entailed with this research. These elements constitute the first references for a proposal of indicators to be integrated in the impact assessment methodology, wider and able of being used in similar cases, as mentioned in the initial part of this introduction.

\section{Gondomar Polis Programme}

\subsection{The Polis Programme}

The POLIS Programme was a Portuguese financing scheme initiated in 2000 by the central government in partnership with the local city authorities. The valorisation of environmental structural elements, as riverfronts, was one of the main strategies of the programme, aiming to improve the quality of public green spaces on cities and, in consequence, the quality of the urban environment. Globally, 28 large integrated operations and 12 minor interventions were carried away in 39 Portuguese cities.

\subsection{Gondomar Municipality}

The Municipality of Gondomar is inserted in the Porto Great Metropolitan Area, located on a peripheral position to the East of Porto. Comparatively to the other adjacent municipalities of Porto metropolitan area (PMA), Gondomar presents the sociodemographic characteristics summarized in the table 1.

Gondomar gives continuity to the Douro riverfront along circa $35 \mathrm{Km}$. Over the last decades the urban pressure on this area became progressively stronger. The scarcity of land with river or seascapes in the city of Porto leaded to a crescent urbanisation of these margins, simultaneously threatening the environmental characteristics of the area and generating an 
increasing phenomenon of gentrification. Another weakness of this area was the puzzle that composed the land ownership, mixing public with private properties.

Nevertheless, this riverfront is one of Gondomar's major environmental opportunities to improve the quality of life in the municipality. This front has potential to promote sustainable environmental, social and economic development in the years to come. Aware of this territory opportunities and threats, the municipality commissioned a Strategic Plan covering $14 \mathrm{Km}$ of this margin (from Porto to the Crestuma/Lever Dam), which was executed in $1999 / 2000$.

\subsection{Gondomar Polis Project}

Based on the strategic plan framework, the municipality submitted in 2001 the requalification of $4.5 \mathrm{Km}$ of this riverfront to the National Polis Programme competition ${ }^{7}$. The project was approved in 2001 and started in March 2002. The total financing of the operation amounted on $€ 14,963,938.00$, supported in $90 \%$ by the Portuguese Government and in $10 \%$ by the Municipality. The project was targeted to be finished in December 2009.

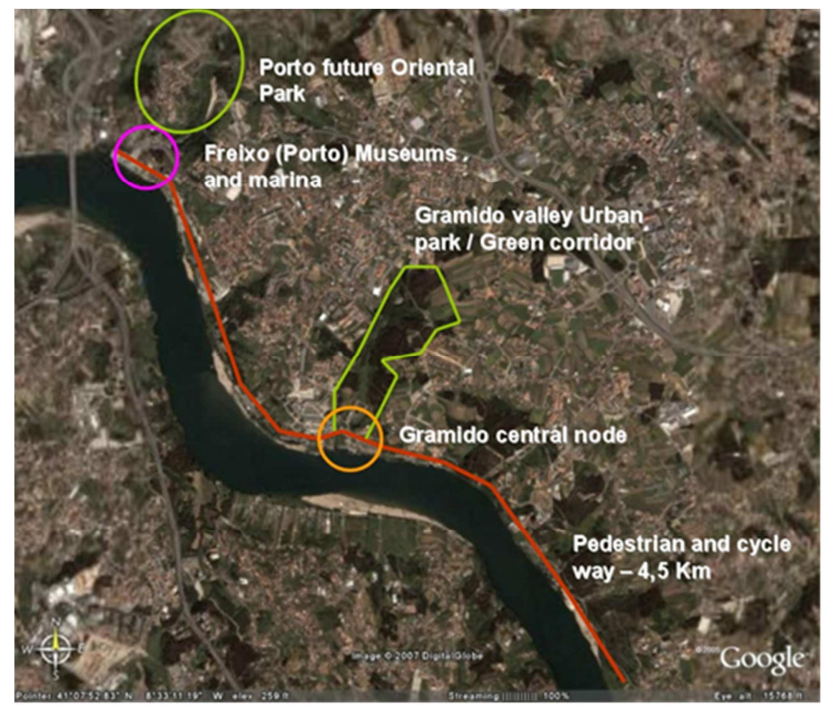

Figure 1: Gondomar Polis Programme strategic development (Google Earth imagery)

The approved urban operation covered an area of 44 ha, delimited by the council of Porto (west), the River Douro (South), the national road 180 (North) and the historic Property of Atães (East). It covered the Parishes of Valbom and Gondomar ( $\mathrm{S}$. Cosme), the two

\footnotetext{
${ }^{7}$ This POLIS operation was inserted in the Programme Component 4: Complementary measures to improve the urban and environmental conditions of the Cities.
} 
riverfront administrative units closest to Porto. The urban project targeted a extensive infrastructural and environmental requalification along the River Douro, including the transformation of the area in a vast public green space with cycling and pedestrian routes, giving continuity to the Porto riverfront, envisaging a metropolitan strategy (figure 1). Additionally, the operation aimed to conserve the natural characteristics of the zone and promote their sustainable leisure and socioeconomic development. The valorisation of the Gramido Valley green corridor was also included (figure 1).

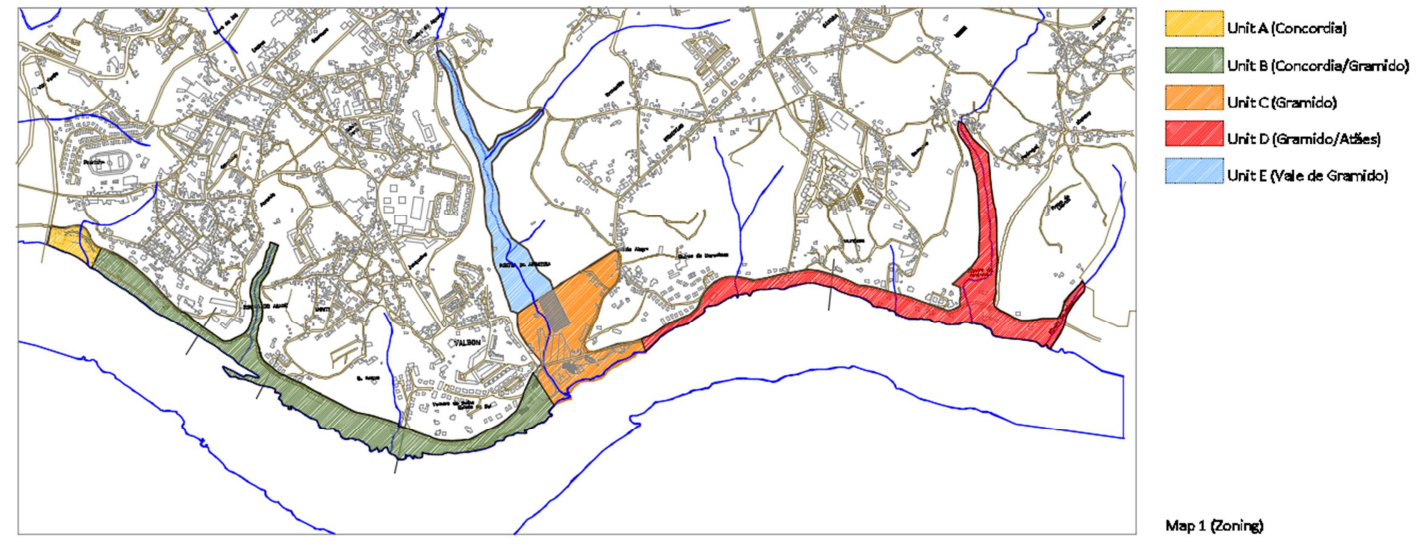

Figure 2: Project Units defined on the Preliminary Plan

The strategy was deepened in 2002 through a preliminary plan which defined five project units $(A, B, C, D$ and $E)$ which were related with the landscape units identified through the site survey (figure 2). The plan also detailed the programme in accordance with the existing place conditions, and defined the urban design criteria to be met by the project teams. The constrains posed by the river Douro continuous floods were also identified and a specific design criteria to dealt with it was proposed.

The strategic and the detailed preliminary plans, defined several concrete operations divided in two categories: surveys/studies and projects/construction works.

The survey and studies included: Implementation of a Geographical Information System (GIS) for the management of the area; Elaboration of a Sight Plan, giving rules for the mitigation of the landscape problems detected; River pollution surveys to detect and correct the illegal sewer connections; Environmental Impact Assessment study of the intervention.

The Projects and subsequent construction works embarked the following: The waterfront requalification, including the construction of the pedestrian and cycle way $(4,5 \mathrm{Km})$ and the requalification/creation of green and public spaces; The rehabilitation of the Gramido's Historic House (Casa Branca de Gramido) to be used by public functions; The construction of 
the Gramido Nautical Centre (rowing), to promote the leisure and sport activity, and bring a young population (rowing school and competition activities) to the historic site of Gramido; The construction of the Gramido car parking, supporting the activities in the central area of the operation; The conversion of a rural farm to an environmental education centre, which was also intended to function as a gate to the future urban park to be implemented in the Gramido Valley; The Gramido wastewater treatment plant (ETAR) remodelling, in order to improve their treatment efficiency.

\subsection{Development of the operation}

The operation started officially in March 2002 and the first two years were devoted to perform surveys, plans and projects. A partnership was established with the Gondomar Water Company (Águas de Gondomar, SA), which take over the financial and administrative responsibilities for the River pollution surveys and for the Gramido's ETAR remodelling operations. During the project's development, the metropolitan water supplier company (Águas do Douro e Paiva) expressed their interest on installing their Porto's water pipeline supply under the intervention along the river margin. This process was institutionally agreed and all the projects for the margin units were remodelled in order to coordinate the global intervention, delaying the Polis construction works in circa one year. In parallel with the projects, several administrative processes were executed in order to expropriate the private land needed to implement the Polis intervention. The necessary funding revealed to be higher than the initial budgeted, affecting in special the Unit $D$, where the large number of private properties and the significant area they occupied were factors which leaded to the suspension of the project, which was abandoned and removed from the Polis intervention. Also the intervention area of the Unit E was reduced exclusively to the Environmental farm project.

The construction work started with the remodelling of the Historic House of Gramido in 2005 and finished with the construction of the Quinta do Passal Environmental Farm in 2011. However, due to some land expropriation delays it was necessary additional construction work to complete the last 100 meters of Unit B in 2013 (table 2). The diverse time of completion of the construction works turns difficult on establishing a concrete date for the start of the operational stage of the intervention. However, is possible to point out 2013 as the year when most of the interventions were fully operational: the conclusion of the installation works, the opening of several cafeterias along the cycleway, the opening of the Environmental Farm, amongst others. The exception was the Historic House of Gramido, 
which started to function as a cultural and touristic public building only in 2014 , after some scarce and periodic opening periods since their official inauguration in 2006. The gap verified between the end of the construction work and the beginning of the full operation stage, leaded to some insecurity and lack of use of the public spaces in certain periods. This was aggravated by the delay of public services on performing the complete maintenance of the space. This situation was only mitigated in $2013 / 2014$, with the full operationalization of the intervention and of the maintenance services. However, it is still visible along the riverfront some evidence of degradation.

The final indicators of the intervention are listed in table 3 . These correspond to the official indicators system of the National Polis Programme. Even if the intervention was not fully completed, is possible to confirm that these values are expressive, revealing how the intervention deeply transformed this area.

\section{System of indicators}

\subsection{Thermal Comfort}

Thermal comfort is a particularly important notion with regards to the creation of new urban areas or rehabilitation of existing ones. This is even more important considering the current trend for the pedestrianisation of urban areas in a climate change context. Thermal comfort should be herewith understood as "that condition of mind which expresses satisfaction with the thermal environment» (ISO, 2005; 10).

\subsubsection{Field survey}

The field survey relates to the data collection in situ - Gondomar riverfront. Framed by the overall objectives for this exercise, the undertaken field survey was thought as a fundamental means for identifying the thermal comfort conditions actually delivered to people at the area selected as case study. The field survey combined the collection of objective (morphologic characterisation) and subjective (questionnaires) data while paying attention to the importance of empirical data on the (subjective) human parameter in outdoor spaces. The aim was to address the analysed microclimates on the perspective of how people actually 'perceive' it. 
The field survey then consisted of a morphologic and a social/personal analysis. The morphologic analysis allowed collecting data about the physical layout of the analysed area. In turn, the social/personal analysis gathered information on the spaces' users, their personal evaluations about the microclimate of the area. The function of the space has naturally been considered during this exercise. The field survey covered a six-day period: two week days and four weekend days. Two of the week days and two of the weekend days presented slightly overcast situations. The remaining two weekend days presented clear conditions actually very close to a 'typical summer day' in Porto. These were two days of an exceptional character typically occurring each year by the time the field survey was undertaken. The field survey was undertaken between 3 p.m. and 6 p.m. This corresponds to the period people most use the space due to its recreational character. Between 9 a.m. and 11 a.m. one may also observe a significant usage. Nevertheless, during this morning period people are engaged in activities related to sport which makes them less available for answering a questionnaire.

\subsubsection{Results}

\section{Morphologic analysis}

The field survey allowed understanding that there are no substantial morphologic differences between the three analysed sites. Most of the parameters (orientation, H/W ratio and SVF, main colours, water, shading devices, ground facing materials, façade facing materials, and vegetation) present basically the same conditions which are synthesised in table 4. Such as shown on table 5, some differences are however established between the percentage of shade provided by vegetation at solar noon, permeable paved surface, impermeable paved surface and permeable green surface.

Table 5 shows that site 1 presents the highest amount of shade provided by vegetation (a function of the amount and positioning of specimens with the shaded provided to the areas used by pedestrians) $-22 \%-$ whereas site 3 presents the lowest percentage $-2 \%$. For all three cases it is put into evidence that the percentage of shade is low considering the orientation of the sites. Relatively to the ground permeability to water, the morphologic analysis allowed understanding that for the three analysed spaces the percentage of paved impermeable area significantly surpasses the percentage of permeable surfaces, either paved or green. There is therefore a clear predominance of paved areas. Relating all results observed for the morphologic analysis one main conclusion can be drawn about the layout 
of the analysed spaces: in the absence of significant morphologic differences between the three sites except for the shade provided by vegetation and the ground permeability to water, the thermal comfort conditions delivered to pedestrian are likely to be related to these two last parameters. As the analysed spaces are representative of the whole area under study, it can be argued that this is a situation able of being generalised to other sites within this area.

\section{Social/personal analysis}

The questionnaire provided relevant information with regard to the comfort appreciation people do of the three analysed sites. The answers obtained at the three sites presented no substantial differences. Therefore, the results for the social/personal analysis will be presented in terms of global answers, obtained at the three sites. The questionnaire itself was sub-divided into three interrelated sections: thermal sensation, thermal evaluation and long-term evaluation. The five questions unfold from these three sections. The first two sections were based on the considerations of the ISO 10551 standard and refer to the two most fundamental judgement scales - thermal perceptual scale and thermal evaluative scale. The combination of answers on these scales can provide the most fundamental information for judging the subjective human parameter. In what concerns to this parameter, it was observed a clear predominance of people stating a 'neutral' sensation (54\%), i.e. feeling neither warm nor cold. This is a sensation correspondent to the theoretical notion of thermal comfort considered in this study. The remaining votes were divided between 'slightly warm' (24\%), 'warm' and 'slightly cool' (10\% each), and 'hot' (2\%). The votes obtained for thermal evaluation are even more contrasting than those obtained for thermal sensation, with $86 \%$ of respondents stating to feel comfortable at the moment of the interview. The remaining $14 \%$ are shared somewhat evenly between 'slightly uncomfortable (warm)', 'uncomfortable (warm), and 'slightly uncomfortable (cool)'. Relatively to the identification of the most unpleasant climatic variable at the moment of the interview, most respondents (56\%) referred that no variable was a cause of discomfort. In turn, $25 \%$ referred direct solar radiation, $15 \%$ wind, and $4 \%$ mentioned air temperature and relative humidity. Considering the proximity of the river and the orientation of the space it is surprising to observe that no climatic variable was causing discomfort to most people whereas it was expectable that wind and sun would be considered as relevant sources of discomfort. With respect to the summertime long-term evaluation votes, it was also surprising to observe that the votes share nearly the same percentages: $48 \%$ of 
respondents stated that the analysed spaces were uncomfortable during summer whilst $52 \%$ considered it comfortable during the same season. This means that half of the users feel keen to use these spaces during summer typical days whereas the other half does not. Wintertime long-term evaluation votes present a different situation: $79 \%$ of respondents considered the analysed sites as uncomfortable during typical winter days whereas $21 \%$ considered them as comfortable. In this case, it is concluded that most people perceive the area as uncomfortable during winter so they do not feel keen to use it during this season. Considering the orientation of the sites and the predominant absence of elements able of providing shade during summer and wind/rain sheltering during winter, it was surprising to observe that most people were feeling thermally neutral and, consequently, comfortable at the moment of the interview (it should also be considered that votes falling out the comfort range where still very close from it - a slightly uncomfortable category which may correspond to slight breezes of slightly higher body temperatures); that for most respondents no climatic variable was causing discomfort during the interview. Most importantly, the long-term evaluations people made offered relevant information from starting to infer about the thermal comfort conditions offered by the analysed sites. The nearly even percentages for the 'usually comfortable' or 'usually uncomfortable' categories show that compared to public spaces of different uses and functions but with similar morphologic features, the analysed sites account with a higher tolerance by its users. The same cannot be said for wintertime conditions, when people's votes are more contrasting.

\subsection{Economic Values}

\subsubsection{Framework}

This system integrates parameters that allow understanding the territory's economic valuation based on the following statistical subjects: companies and territory, jobs framework, construction and housing and real estate. It was elaborated based on a selection of statistical data from several sources, namely, the Municipality of Gondomar, the Portuguese National Statistical Institute (Instituto Nacional de Estatística - INE) and the Confidencial Imobiliário - $\mathrm{Cl}$ (a national reference to measure the residential market valuation). 


\subsubsection{Method}

The economic analysis of the studied area is focused on the direct and indirect relevant values created by the urban project under analysis. The evaluation parameters therefore integrate data about the economic values created within the study area as well as the economic values leveraged by the project in the area surrounding it, namely the construction and economic valorisation of the real estate in the surrounding units (table 6).

\section{Created economic values}

The economic values created within the study area are framed by the themes: 'companies and territory' and 'job market'. In what relates to the parameters of the theme companies and territory, these correspond to the economic activities and public services measured with consideration, respectively, to the number of commercial units and the number of facilities created in the area. These numbers are associated to the created direct job positions related to the job parameters. Relatively to the subject job market, the parameters refer to job, more precisely to the number of created job positions, direct or indirectly.

\section{Leveraged economic values}

This class of economic values integrates parameters framed by the subjects: 'construction and dwelling' and 'estate market'. The first accounts with parameters targeted at describing the built dynamics through the identification of the number of concluded and built buildings, encompassing a temporal gap including the years of conclusion of the project. For the selection of these parameters it was considered that the investments made in for built and dwelling might have been influenced by the preparation and concretisation of the project even if firstly confined and conditioned by territorial-based factors related to soil use or to the geographic placement of the study area. In what concerns to the theme 'estate market', it was considered that the parameters related to buying and selling and leasing markets for the area's dwellings only, since the average rents per square meter for commercial units were only found for the council scale of analysis. 


\subsubsection{Results}

\subsubsection{Created economic values}

\section{Companies and territory}

With the purpose of favouring an economic model based on tourism and recreational development, centred on the respect for the environment, the preservation of natural heritage and rehabilitation of the existing built environment, the project accounted with the facilities supporting the touristic activities as well as those related to existing environmental education and sports. Some food and drinks commercial units have also been created with the same purposes.

\section{$\underline{\text { Facilities }}$}

According to the data provided by the City Council, utterly confirmed through the undertaken field survey, four distinct facilities were created within the study area: tourism interactive shop, cultural space, environmental farm, and nautical centre. The two first facilities are located at Casa Branca de Gramido, a listed and refurbished historical building, where the objective was to conceal the touristic and cultural spheres. With respect to the last facility, this results from the intervention on a pre-existing farm, Quinta do Passal, and it constitutes the first and only structural reference of Gondomar council in terms of environment.

\section{Commercial units}

Such as for the facilities, the data related to the commercial units was obtained through the City Council and, utterly, validated through the field survey. According to these data, the commercial units built by this scheme were five: four bars along the riverfront and one restaurant and bar integrated in the nautical sports centre.

\section{Job market}

The data collected suggests that the amount of job positions created through the insertion of the activities present at the study area rises to 61, amongst which 49 are direct and 12 indirect. These job positions belong to services, a sector that in the past few decades has been growing significantly in the country. Most of the direct job positions (37) are 
concentrated in the commercial units particularly those created in the nautical sports centre. The remaining ones (12) can be found spread over the facilities. These results seem to fit the offered service capacity. On its turn, this capacity seems to be reasonably proportioned to the dimension and requirements of the demand, expressed by the amount of users identified in the systems of uses indicators. This means that the risk for these positions to be extinguished by lack of response of the offered service is residual. The only exception here can be considered to be the part-time job positions. In most cases, these job positions constitute a support for ensuring or reinforcing the capacity of the services during days or periods of larger activity, in which the demand is higher. In what concerns to the indirect job positions (12), they all correspond to full-time jobs and are an indirect consequence of the delivered scheme since these are related to the need of implementing a public space maintenance service.

\subsubsection{Leveraged economic values}

\section{Construction and housing}

As expected, since the 2000's the construction dynamics shows a decreasing trend. Following a period of high urban expansion between the 70's and 90's, both at national level and in the research area, and despite some occasional growing periods (figure 3), the construction reveals a decreasing pattern accordingly with the demand saturation. The global economic framework directly influenced this demand, which was also affected by the reduction on the banking housing loans ${ }^{8}$.

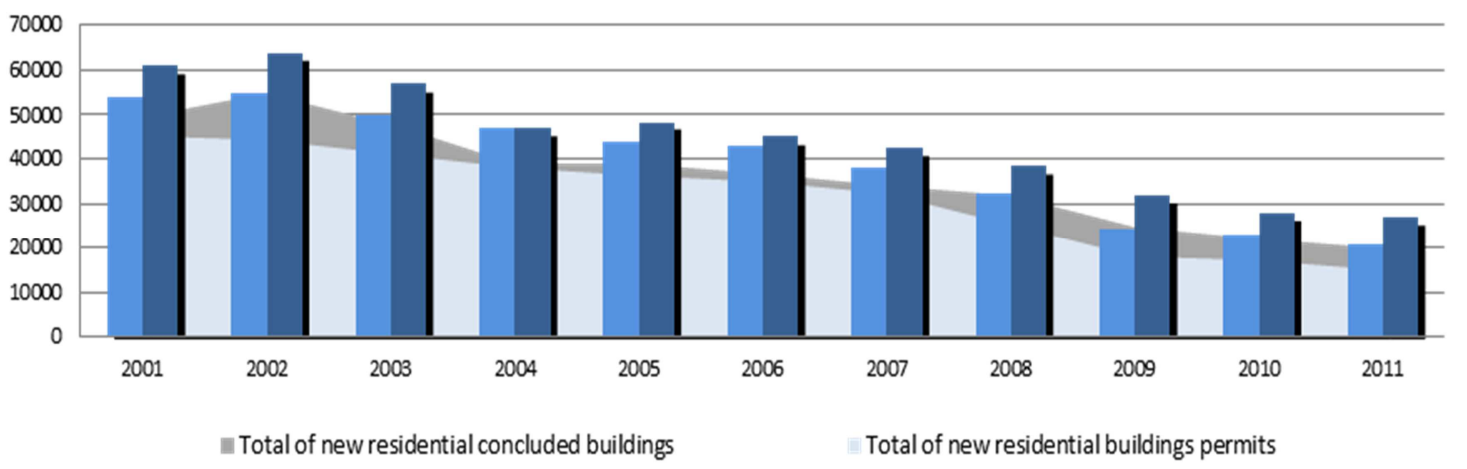

Figure 3: Evolution of the residential buildings permits and concluded 2001-2011 (INE 2012)

\footnotetext{
${ }^{8}$ Accordingly with the Boletim Económico do Banco de Portugal (2010, p. 47-48), (...) the decrease in the housing loans made by the banks for private housing acquisition started in 2006, when the growing rate was higher than 11\%, and aggravated in 2008 and 2009 in the context of the economical and financial crisis, reaching the minimum of $2,3 \%$ in July 2009.
} 
On approaching the analysis of this construction trend in the considered statistical units (Gondomar Council; Parish of Valbom, where the case study area and its surrounding area are included; the corresponding statistical subsections; the surrounding Parish of S. Cosme, which was partially included in the initial project), it is possible to verify that the number of concluded buildings started to gradually decrease since the 90 's (figures $4,5,6,7$ ).

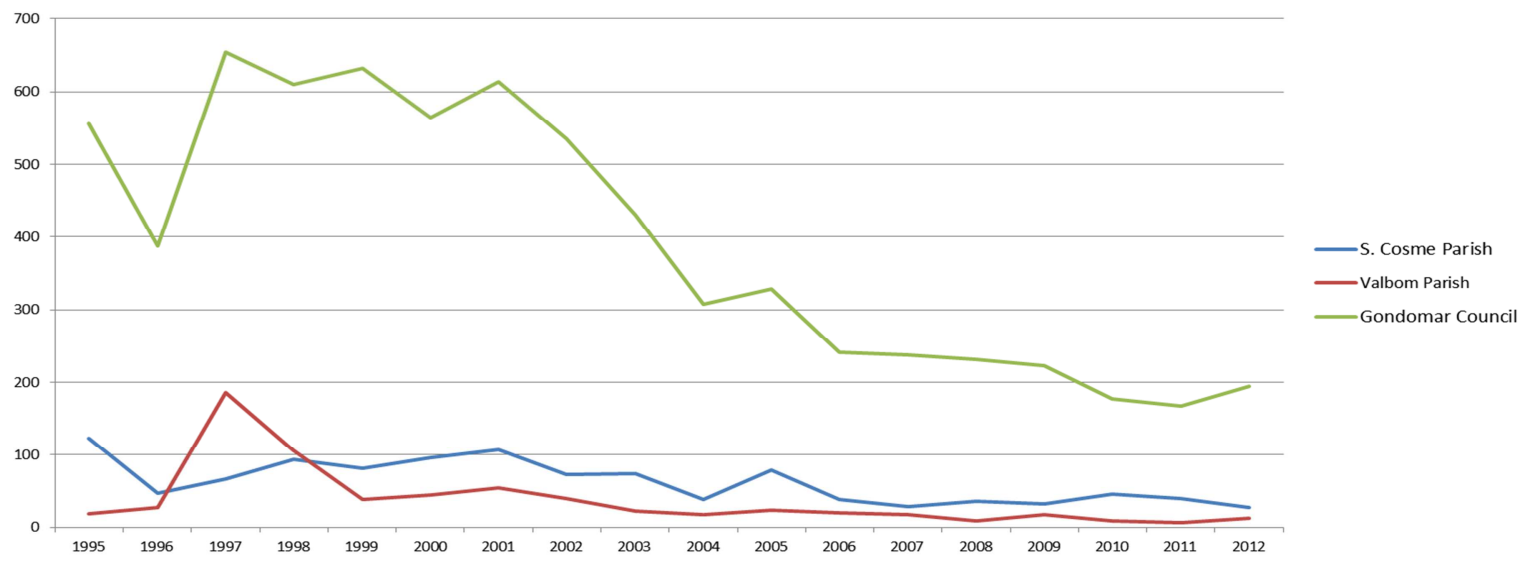

Figure 4: Number of concluded buildings (INE 2012)

Moreover, when comparing the percentage change of the new buildings, is possible to confirm that the major decrease occurred in the selected surrounding area statistical subsections.

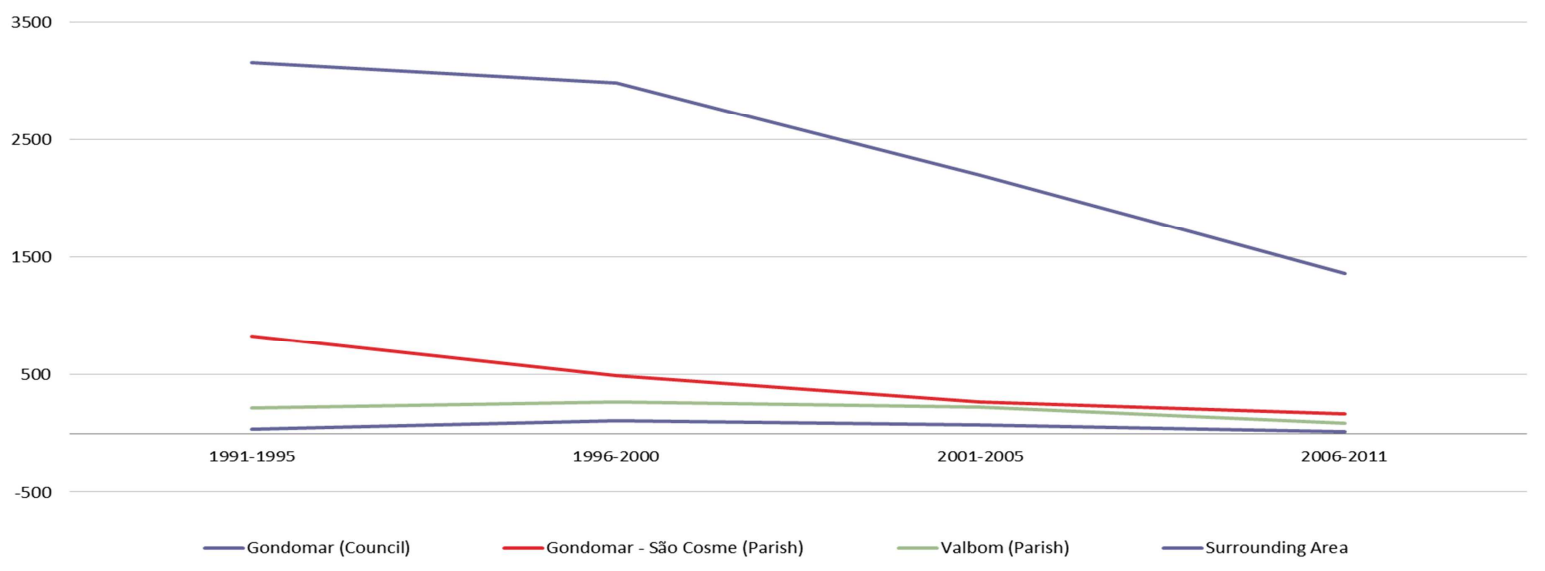

Figure 5: Number of new buildings (INE 1012) 


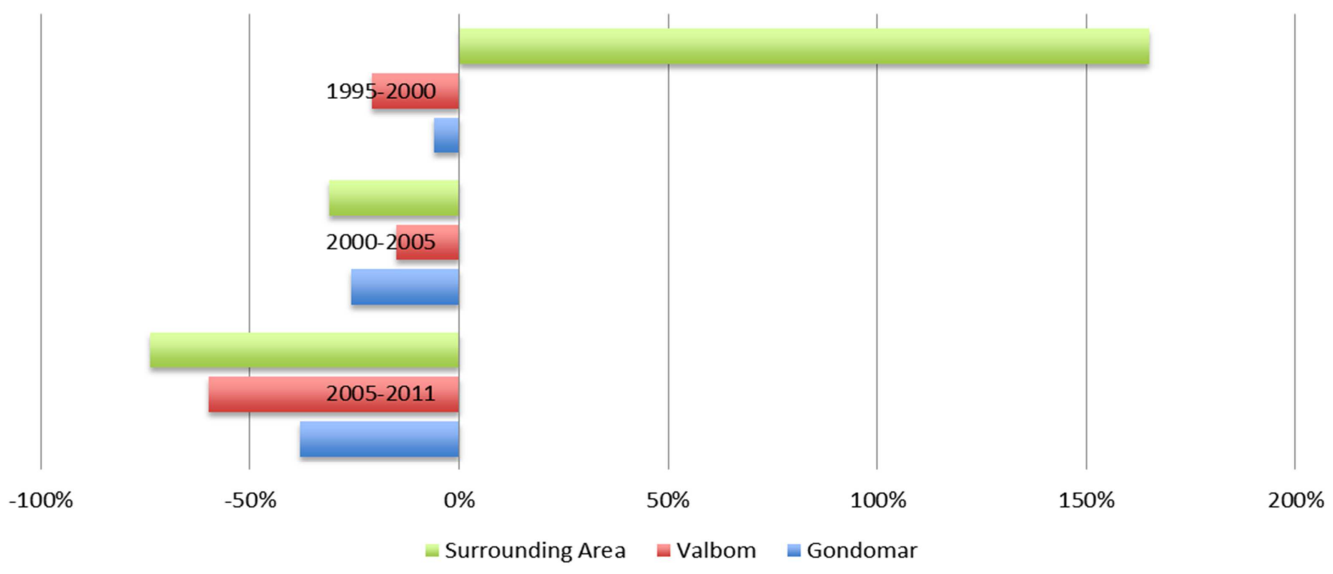

Figure 6: New buildings - proportional variation \% (INE 2012)

Nevertheless, despite the significant reduction on new buildings, and contrarily to what it could be expected, a more careful analysis of the data allowed understanding that the total number of buildings in the influence zone has been progressively growing. Higher values from those observed in other statistical units are presented here (figure 7).

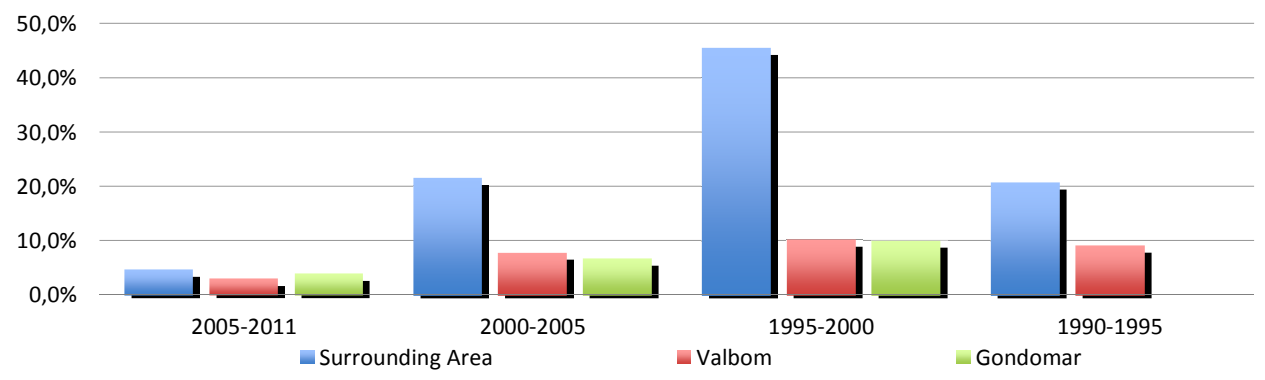

Figure 7: Total of buildings - proportional variation \% (INE 2012)

On one hand, this interpretation confirms the influence, reduced but doubtlessly continuous, with respect to the territorial-based valorisation factors, namely the riverfront landscape, the proximity to Porto and the presence of accessibilities that favour the mobility and access to the surrounding centralities. These factors have contributed along two decades to the increment of population density and, specially, fostered the concentration of countless dwellings, mainly single-houses, many of which directly facing the river. These cases are targeted at medium and medium-high classes. On the other hand, it should be considered that this progressive and continuous concentration, although tending to decrease, might have been utterly influenced by the intervention at the study area. In this sense, the Polis project has been acting as a catalyst in the process of consolidation of the surrounding urban areas. In this context, the undertaken analysis shows that these buildings have been built between 2003 and 2006. This corresponds to the period when the 
intervention in the study area was prepared. The higher reduction, in terms of the number of buildings built in the influence area, is observed in fact only after 2006 when the first signs of the economic and financial crisis have come into light ${ }^{9}$. It is not possible to conclude that the Polis project had a strong and decisive influence in the construction dynamic. However, the results allow suggesting that it could have influenced the concentration of new buildings in the surrounding area. This hypothesis seems to gain strength when crossed with the following analysis, which shows that the economic valuation of the residential buildings occurs accordingly with the finishing of the Polis Project.

\section{Real Estate market}

The available data for the theme refers to information for the Council and the Parish only. For this reason it was not possible to assess the effects of the estate valorisation brought by the project in a direct and detailed way. Still, it was considered that it would be precisely in this area that a significant part of these effects were to be felt since this is an area possessing territorial-based characteristics making it more appealing to the construction and estate sectors. Therefore, after analysing the available data, it was observed that there is a trend for a major and progressive estate valorisation at the Parish where the study area is located in. This is true for both buying and selling as well as for rentals (figures 8 and 9).

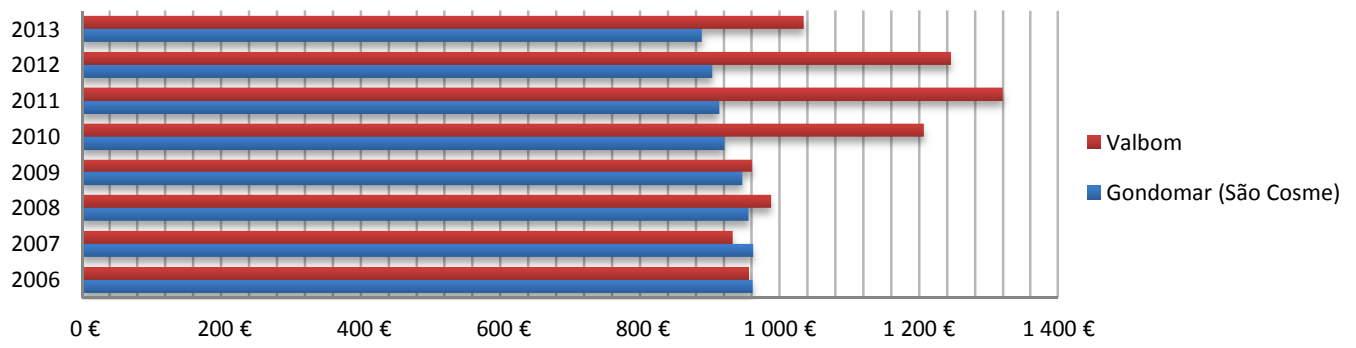

Figure 8: Offer value per $\mathrm{m}^{2}$ in the purchase or sell of dwellings (Source: $\mathrm{Cl} /$ LardoceLar.com)

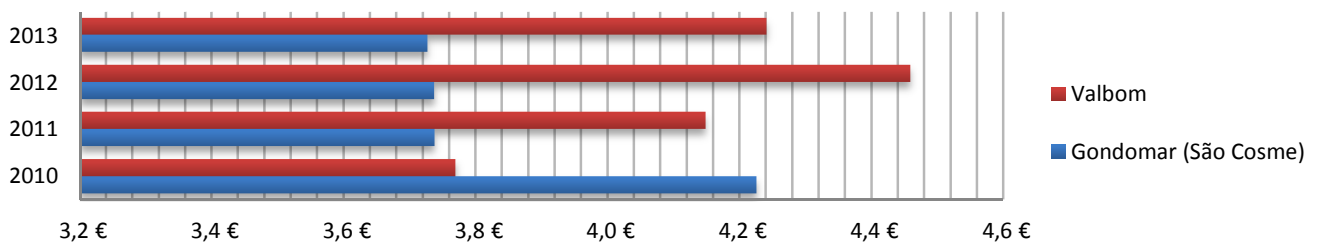

Figure 9: Offer value per $\mathrm{m}^{2}$ - Dwellings renting (Source: $\mathrm{Cl} /$ LardoceLar.com)

\footnotetext{
${ }^{9}$ Accordingly with the Census 2011 final results (INE, 2012, p. XCVI), circa 11\% of dwellings were unoccupied. This percentage was slightly above the previous Census data, however, in absolute values the unoccupied dwellings changed from 440,291 in 1991 to 543,777 in 2011, revealing and increase of 103,486 empty dwellings.
} 
It was observed that the highest values for this trend were registered when the project was about to be concluded: 2011 and 2012. This seems to indicate that the values produced by the scheme were no longer connected to the new built but to rebuild of existing buildings. This hypothesis seems even more plausible when analysed in the light of later data showing that for the same period the offer of dwellings were defining a totally opposite trend. This took place not only at the Parish level but also at the national level, showing the lower values ever before 2011 (figure 10).

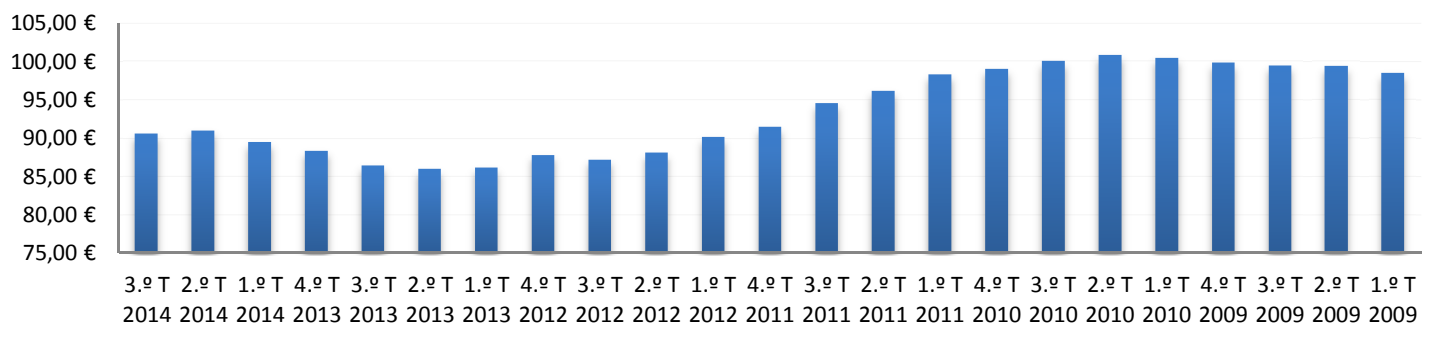

Figure 10: Housing prices index, Portugal; Quarterly

\subsection{Usage}

\subsubsection{Framework}

The study area is structured along a shared route for pedestrians and cyclists, connecting several different spaces dedicated to leisure, sport, social interaction and sightseeing. The access to these spaces is made through several entrances from the national road. Two of these entrances account with a significant area for car parking while the others allow few cars to park. Although there are three entrances allowing a more comfortable and safer accessibility, it was observed that in order to reach the aimed spaces within the study area, the users access it from any point allowing a way in.

Presently, there is still no plain or continuous link to Porto's riverfront. For this reason the area ends up being confined to its starting and ending points and so are the circuits made by people and bicycles. The area is not therefore framed by any pedestrian or bike route of inter-municipal or regional scale such as initially meant in the project. Considering these facts, it was decided to identify the number of users by assessing its density during the days and hours of higher and lesser usage rate in detriment of other methods, usually based in the construction of fluxes for determining the frequency of people arriving and leaving, typical of more complex multifunctional urban environments. The values for more and less busy days were then made through a group of systematic counting of people present at site. 
This counting was made by covering the space in one way only, recording and describing simultaneously and progressively: i) The total number of users found along the way and at the spaces directly associated to it; ii) The total number of users present at the several typologies of permanence spaces (e.g. beaches and terraces). Only at the entrance possessing the highest parking area was found, at the most busy day and during a short interval, a number of cars entering and leaving immediately due to the absence of free places.

\subsubsection{General profile of users}

The undertaken field survey allowed understanding that the majority of users belong to different age groups and integrate not only nuclear families but also larger multigenerational families ${ }^{10}$. It should however be pointed out that the significant presence of large multigenerational family groups was only observed in resting days or under favourable climatic conditions for strolling or leisure. The remaining week days, when the density of use significantly changes, one can specially find people walking alone or in groups of small dimension (2-3 people) made up by the elderly, children with parents, or people practicing sports.

\subsubsection{Results}

\section{Users in permanence and in movement}

The comparative analysis of data related to the total number of users at site (table 8), it was observed that in the busiest day the number of users is particularly significant, corresponding to around twelve times plus the number of users during the less busy day. The observation of the number of still and moving users during the busiest day puts into evidence that the value for the moving ones is around four times higher than the value for people not moving. These facts, coupled with the undertaken questionnaire made in loco, allowed understanding that the main objective of most users is, in fact, strolling. It should also be noted the small number of cyclists in the busiest and less busy day probably due to the absence of plain and direct links between this space and bike lanes at the surrounding councils of Porto and Vila Nova de Gaia.

\footnotetext{
${ }^{10}$ The term multigenerational is applied to families covering four living generations, but it can also be used for families with three generations (Vicente, Sousa, 2007: 158).
} 


\section{Users at the commercial and balneal spaces}

Another aspect worth highlighting is related to the number and type of users identified at the commercial units and balneal spaces (table 9). With respect to the commercial units, during the busiest day all were found packed whilst during the less busy day these were nearly empty. The main reason for this seems to be the fact that users look for highlyqualified spaces for socializing, in this case in direct connection to nature. Therefore, the large majority of users were found at these resting areas. In what concerns to the balneal spaces, it was observed the same situation. It is believed that during summer the occupation rate of these beaches can be even more intense.

\section{Car parking}

During the busiest day, all car parking areas were found to be completely packed. For this reason many vehicles were found parked out of allowed spaces. After analysing the in and out fluxes, it was possible to conclude that there is a high demand for parking and a significant number of people not able to find an official parking place. The eventual increase of parking places would allow overcoming this situation but, however, would attract more users.

\section{Conclusions}

\subsection{Thermal Comfort}

The undertaken field survey offered important and surprising information about the relationship between the layout of the analysed spaces and the way people perceive it and, thus, use it - people feel pleased with the analysed area from a thermal perspective although it does not present the ideal conditions from the theoretical point of view. The surprising tolerance of people to the conditions offered by the layout of the analysed sites was perhaps the most interesting aspects of this study. The orientation of the sites and the predominant absence of elements able of providing shade during summer and wind/rain sheltering during winter would lead to consider that these spaces would not obtain so positive answers with regard to the delivered comfort conditions. These spaces face south and have few features where people can get protection from the climatic variables. For 
typical winter days, where wind and rain can be a significant cause of discomfort at the site, the answers obtained to the questionnaire are in line to what it would be expected. However, in typical summer days, where air temperature and direct solar radiation can be quite high at site's latitude, it would be expected for people not to be able to cope with the area's microclimate. However this seems not to be the case since a significant number of users considered the space comfortable at the moment of the interview and in a long-term perspective.

Three main topics can be brought into discussion here as possible causes for this fact: offer of public spaces, function, and landscape. 1 . This riverfront is the only large scale qualified public space offered to local populations. It is therefore plausible that people find in it the only chance for being engaged in social activities. 2 . The function of this area has the potential to state it as attractive by its own right. This is an area dedicated to leisure and sports in close relation to Douro River. It therefore becomes a privileged area for people to embark in these activities. 3. Despite its proximity to dense urban areas, this is an area of outstanding natural beauty where people can find an opportunity to distress from the common impacts of urban areas and daily life and, simultaneously, observe a remarkable landscape. Together, these three topics may be at the basis way people feel so keen to use the area even though it lacks qualification parameters commonly considered as fundamental for the use, social meaning and thermal comfort of public spaces

\subsection{Economic Impact}

The created economic values correspond, generally, to those planned in the project. These values comprehend activities and job positions aimed at allowing an array of services. This is meant to promote the development of a local economy based on tourism and culture even though the educational component has been conceived for playing an important role on raising awareness for environmental sustainability issues. This transcends the economic objective. It can be said that the created economic values constitute a benefit for the socioeconomic development of the territory at the local and regional levels. The activities implemented in the study area are working properly and creating a reasonable and relatively stable amount of full-time jobs. This evidence, together with the fact that there is a good intensity of use at the delivered public spaces and commercial units, allows concluding that, in a general way, the intervention is successful and has produced positive urban effects. With respect to the triggered values, notwithstanding the raised issues, it is considered that the influences of the development and implementation process are 
plausible. Thus, the production of new buildings as well as the valorisation of the estate market were somewhat boosted in the indicated periods by an expectation over the increase of buy and sell, and renting values that follow from the implementation of the project. The identification of triggered values confirms the production of indirect and eventually long-term effects brought by the project.

\subsection{Usage}

The first conclusion to be drawn about the usage analysis is that the project was well succeeded in the sense that it was shown that most of its spaces were able to reclaim the capacity of this area to attract a significant number of users. It is however considered that this capacity might have been influenced of potentiated by the fact that the study area is localised in a territory lacking of qualified public spaces for leisure. The outstanding natural beauty of the site can also be brought into discussion here. This is probably one of the most relevant factors for achieving a good level of use and, thus, a positive evaluation with respect to the success of the scheme. It was however observed that the capacity for attracting users is valid for resting periods such as holidays or weekends. During working days the usage rate is, indeed, rather low although during the field survey the climatic conditions were quite favourable. One of the most plausible reasons for this is the low density and residential character of the urban areas surrounding the space and where urban and functional sprawl is predominant. Another important conclusion to draw here is related to the potential the study area holds for significantly increasing its number of users. This potential, which is clearly stated out by the intense demand for parking during busiest days, can be translated to an increase of parking places not compromising the permeability and other natural qualities of the site but also to the strengthening of public transportation.

\subsection{Current research and further work}

As mentioned earlier, the herewith presented research is a preliminary stage of a broader methodology to be developed shortly. This first stage is currently concluded and submitted to the host/funding institution. The premises brought up with this stage for measuring the impacts of urban projects had as reference their success - the ability of delivering significant and positive benefits for the area, its local communities, economies and environment. 
It should be kept in mind that these principles will integrate a complete methodology for assessing the success of urban projects to be developed in 2016. Following the findings from this preliminary stage, the second and final stage of research will be focused on (1) synthesising the reasons allowing to assess the success and the precise effects delivered by urban projects in the past few decades in Portugal; (2) inferring about the pertinence and extensibility of the preliminary system of indicators, integrating complementary evaluation parameters and criteria able of improving their ability to be used in different case studies; (3) building a system of indicators for evaluating the parameters related to the urban and territorial effects/impacts of urban projects after their completion bearing in mind its success, establishment, functioning and usage, and production of direct and indirect economical values. In conclusion, this new stage of research will give continuity to the preliminary stage, herewith presented, validating its results. Again, this will be a joint work with partner institutions allowing to give a higher deepness and robustness to the results obtained in this first stage of research.

\section{References}

AMADO, M. (2012). Planeamento Urbano Sustentável. 3 ed. Casal de Cambra, Caleidoscópio.

BALSAS, C. (2004). "Measuring the livability of an urban centre: an exploratory study of key performance indicators." Planning Practice and Research, 19(1): 101-110.

BANCO DE PORTUGAL (2010). "A Economia Portuguesa em 2010." Boletim Económico, 16: 9-111.

ECORYS (2011). Desenvolvimento urbano sustentável em Portugal: uma abordagem integrada. Relatório para a Direcção-Geral da Política Regional da Comissão Europeia. Rotterdam, ECORYS.

FERRETTI, L. V. (2012). L'architettura del progetto urbano. Procedure e strumenti per la costruzione del paesaggio urbano. Milan, Franco Angeli.

HOGG, S., MEDWAY, D. and WARNABY, G. (2001). Towards a Typology of Marketing Town Centre Management Schemes through the use of KPIs: WPSO18. Manchester, Manchester Metropolitan University Business School [http://www.ribm.mmu.ac.uk/wps/papers/01-11.pdf] (Accessed 2/12/2014).

INE (2002). Censos 2001: Resultados Definitivos. XIV recenseamento geral da população. IV recenseamento geral da habitação. Lisbon.

INE (2012). Censos 2011: Resultados Definitivos. XV recenseamento geral da população. V recenseamento geral da habitação. Lisbon.

ISO (2005). ISO 7730. Ergonomics of the thermal environment - Analytical determination and interpretation of thermal comfort using calculation of the PMV and PPD indices and local thermal comfort criteria. Geneva, International Organization for Standardization.

Lynch, K. (2006). L'immagine della città. Venice, Marsilo.

MAJOOR, S. J. H. (2008). Disconnected Innovations. New Urbanity in Large-Scale Development Projects: Zuidas Amsterdam, Ørestal Copenhagen and Forum Barcelona. Amsterdam, UVA Universiteit van Amsterdam. 
MAOT (2000). Programa de Requalificação Urbana e Valorização de Cidades. Lisbon, Ministério do Ambiente e Ordenamento do Território.

MAOT (2002). Polis em Números. Lisbon, Ministério do Ambiente e Ordenamento do Território.

MAOTDR (s.d.). Política de Cidades Polis XXI. Lisbon, Ministério do Ambiente, do Ordenamento do Território e do Desenvolvimento Regional.

MARINONI, G. (2005). Metamorfosi del Progetto Urbano. Milan, Franco Angeli.

MORRIS, P. and THERIVEL, R. (eds.) (2009). Methods of environmental impact assessment. 3 ed. London, Spon Press.

OQ (2010). Abordagens integradas de Base Territorial: Relatório final. Lisbon, Observatório do QREN.

PARTIDÁRIO, M. (2007). Guia de boas práticas para Avaliação Ambiental Estratégica-orientações metodológicas. Lisbon, Agência Portuguesa do Ambiente.

PELUCCA, B. (2010). Progetto e Rinnovo Urbano nella Città Contemporanea: Il Caso del Portogallo. Saonara (PD), II Prato.

PEREC, G. (1989). L'Infra-ordinaire. Paris, Seuil.

PORTAS, N. and CABRAL, J. (2011). Inovação nas políticas urbanas. Estratégias, planos e projectos. Políticas Urbana II - Transformações, Regulação e Projecto. Lisbon, Fundação Calouste Gulbenkian: 257-373.

QUEIRÓS, M. and VALE, M. (2005). Ambiente urbano e intervenção pública: O Programa POLIS. Actas do X Colóquio Ibérico de Geografia. Évora, Associação Portuguesa de Geógrafos

VICENTE, H. T. and SOUSA, L. (2010). "Funções na família multigeracional: Contributo para a caracterização funcional do sistema familiar multigeracional." Psychologica, 53: 157-181. 


\section{Annex}

\begin{tabular}{|l|c|c|c|c|c|c|c|c|}
\cline { 2 - 9 } \multicolumn{1}{c|}{} & Metropolitan Region & \multicolumn{4}{|c|}{ Metropolitan Area Surrounding Councils } & Intervention Area Parishes \\
\cline { 2 - 10 } \multicolumn{1}{c|}{} & Grande Porto & V. N. Gaia & Porto & Gondomar & Maia & Valongo & Valbom & $\begin{array}{c}\text { Gondomar } \\
\text { (S. Cosme) }\end{array}$ \\
\hline Censos 2001 (number of inhabitants) & 1260680 & 288749 & 263131 & 164096 & 120111 & 86005 & 14129 & 25717 \\
\hline Censos 2011 (number of inhabitants) & 1287282 & 302295 & 237591 & 168027 & 135306 & 93858 & 14407 & 27047 \\
\hline Population variation 2001-2011 (\%) & 2.11 & 4.69 & -9.71 & 2.40 & 12.65 & 9.13 & 1.97 & 5.17 \\
\hline Area (2011) Km2 & 2041.31 & 168.7 & 41.42 & 131.9 & 82.99 & 77.99 & 4.38 & 11.74 \\
\hline Population Density (2001) inhabitants/Km2 & 617.58 & 1711.61 & 6352.75 & 1244.09 & 1447.29 & 1102.77 & 3225.80 & 2190.55 \\
\hline Population Density (2011) inhabitants/Km2 & 630.62 & 1791.91 & 5736.14 & 1273.90 & 1630.39 & 1203.46 & 3289.27 & 2303.83 \\
\hline Urban Land identified in Planning (2013) \% & 14.78 & 51.30 & 68.93 & 27.79 & 41.38 & 29.13 & - & - \\
\hline $\begin{array}{l}\text { Area of equipment and urban parks } \\
\text { identified in Planning (2013) \% }\end{array}$ & 2.99 & 10.39 & 22.33 & 4.10 & 13.53 & 2.09 & - & - \\
\hline Land used for agriculture (2009) \% & 7.45 & 5.59 & 0.99 & 9.20 & 20.71 & 8.42 & - & - \\
\hline
\end{tabular}

Table 1: Socio-demographic framing of Gondomar within PMA.

\begin{tabular}{|l|c|c|}
\hline Project & Construction work & Operation \\
\hline Historic House of Gramido & $2005-2006$ & 2014 \\
\hline Gramido Nautical Centre & $2006-2007$ & 2007 \\
\hline Unit C & $2007-2009$ & 2009 \\
\hline Unit B & $2008-2010 / 2013$ & 2013 \\
\hline Gramido Car parking & $2009-2010$ & 2010 \\
\hline Unit A & 2010 & 2010 \\
\hline Unit E: Quinta do Passal Environmental Farm & $2009-2011$ & 2013 \\
\hline
\end{tabular}

Table 2: Dates of construction work and operation.

\begin{tabular}{|c|c|c|c|}
\hline Indicator & Predicted & Final & Unit D \\
\hline Intervention Area (ha) & 44.36 & 20.34 & 9.85 \\
\hline Creation and Improvement of Parks and Green Areas $\left(\mathrm{m}^{2}\right)$ & 118,232 & 39,149 & 2,500 \\
\hline Creation and Requalification of Public Space $\left(\mathrm{m}^{2}\right)$ & 10,500 & 11,989 & 2,632 \\
\hline Riverfront Requalification (m) & 4,437 & 2,622 & 1,815 \\
\hline New Pedestrian and Cycle bridges ( $\mathrm{n}$ ) & 12 & 9 & 3 \\
\hline New Cycle Way (m) & 6,055 & 2,931 & 1,970 \\
\hline Conditioning of traffic in existing streets $\left(\mathrm{m}^{2}\right)$ & 3,342 & 3,243 & 0 \\
\hline New Pedestrian Way (m) & 6,055 & 2,931 & 1,970 \\
\hline Dissuasion car parking (number of places) & 420 & 289 & 32 \\
\hline Landscape Requalification of Historical Interest Spaces $\left(\mathrm{m}^{2}\right)$ & 7,854 & 7,854 & 0 \\
\hline \multicolumn{4}{|l|}{ Buildings Rehabilitation } \\
\hline Number & 2 & 2 & 0 \\
\hline Area $\left(\mathrm{m}^{2}\right)$ & 1,083 & 1,083 & 0 \\
\hline \multicolumn{4}{|l|}{ Buildings Demolition for Urban Landscape Requalification } \\
\hline Number & 2 & 2 & 0 \\
\hline Area $\left(\mathrm{m}^{2}\right)$ & 2,211 & 2,211 & 0 \\
\hline Environmental Education Centre (number) & 1 & 1 & 0 \\
\hline
\end{tabular}

Table 3: Gondomar Polis final institutional indicators 


\begin{tabular}{|c|c|c|}
\hline \multicolumn{2}{|l|}{ PARAMETER } & SITE $1+2+3$ \\
\hline \multicolumn{2}{|l|}{ Orientation } & South \\
\hline \multirow{4}{*}{$\begin{array}{l}\text { Height/width } \\
\text { ratio \& Sky View } \\
\text { Factor }\end{array}$} & $\mathrm{H} / \mathrm{W}$ ratio & High \\
\hline & SVF & High \\
\hline & Access to sun & Excessive \\
\hline & Wind conduction & Fair \\
\hline \multicolumn{2}{|l|}{ Main colours } & Miscellaneous \\
\hline \multicolumn{2}{|l|}{ Water } & Non-existing \\
\hline \multirow{2}{*}{ Shading devices } & Public space & Non-existing \\
\hline & Buildings & Non-existing \\
\hline \multirow{3}{*}{$\begin{array}{l}\text { Facing materials } \\
\text { [ground] }\end{array}$} & Material(s) & Several \\
\hline & Emissivity (global) & $\begin{array}{l}\text { High }(0.50-0.95) \\
\text { e.g. asphalt, concrete, wood, plants, soil, sand, white/red/brown/green paint }\end{array}$ \\
\hline & Albedo (global) & $\begin{array}{l}\text { Medium }(0.30-0.50) \\
\text { e.g. concrete, granite, red brick, wood }\end{array}$ \\
\hline \multicolumn{2}{|c|}{ Facing materials [facades] } & Non-existing \\
\hline \multirow[t]{4}{*}{ Vegetation } & Category/ies & Herbs and trees \\
\hline & Height & Medium and adult \\
\hline & Vegetative cycle & Evergreen (herbs) and caduca (trees) \\
\hline & Crown shape & Spread out, oval and circular \\
\hline
\end{tabular}

Table 4: Results from the morphologic analysis - a cross-reference for the three sites.

\begin{tabular}{|ll|l|l|l|}
\hline PARAMETER & SITE 1 & SITE 2 & SITE 3 \\
\hline Vegetation & $\begin{array}{l}\text { Shade (vegetation) at } \\
\text { solar noon \% }\end{array}$ & $\begin{array}{l}9 \%\left(430 \mathrm{~m}^{2}-14\right. \\
\text { specimens })\end{array}$ & $\begin{array}{l}22 \%\left(244 \mathrm{~m}^{2}-8\right. \\
\text { specimens })\end{array}$ & $\begin{array}{l}2 \%\left(152 \mathrm{~m}^{2}-5\right. \\
\text { specimens })\end{array}$ \\
\hline $\begin{array}{l}\text { Ground } \\
\text { permeability to } \\
\text { water }\end{array}$ & $\begin{array}{l}\text { Paved permeable } \\
\text { surface \% }\end{array}$ & $0 \%$ & $0 \%$ & $9 \%\left(612.71 \mathrm{~m}^{2}\right)$ \\
\hline $\begin{array}{l}\text { Paved impermeable } \\
\text { surface \% }\end{array}$ & $\begin{array}{l}\text { Green permeable } \\
\text { surface \% }\end{array}$ & $38 \%\left(1.821,69 \mathrm{~m}^{2}\right)$ & $24 \%\left(264.71 \mathrm{~m}^{2}\right)$ & $25 \%\left(1.701,96 \mathrm{~m}^{2}\right)$ \\
\hline
\end{tabular}

Table 5: Morphologic analysis results - differences established between the three sites.

\begin{tabular}{|c|c|c|c|c|}
\hline VALUES & \multicolumn{2}{|c|}{ SUBJECTS } & \multirow{2}{*}{$\begin{array}{c}\text { PARAMETER } \\
\text { Number of created commercial units }\end{array}$} & COVERAGE \\
\hline \multirow{4}{*}{$\begin{array}{l}\text { CREATED ECONOMIC } \\
\text { VALUES }\end{array}$} & \multirow{2}{*}{$\begin{array}{l}\text { COMPANIES AND } \\
\text { TERRITORY }\end{array}$} & $\begin{array}{l}\text { Economic } \\
\text { activities }\end{array}$ & & \multirow{4}{*}{ Study area } \\
\hline & & Public Services & Number of created facilities & \\
\hline & \multirow[b]{2}{*}{ JOB MARKET } & \multirow[b]{2}{*}{ Jobs } & Number of created direct job positions & \\
\hline & & & $\begin{array}{l}\text { Number of created indirect job } \\
\text { positions }\end{array}$ & \\
\hline \multirow{5}{*}{$\begin{array}{l}\text { LEVERAGED } \\
\text { ECONOMIC VALUES }\end{array}$} & \multirow{2}{*}{$\begin{array}{l}\text { CONSTRUCTION } \\
\text { AND DWELLINGS }\end{array}$} & \multirow{2}{*}{$\begin{array}{l}\text { Construction } \\
\text { dynamic }\end{array}$} & Number of built and finished buildings & \multirow{2}{*}{$\begin{array}{c}\text { Parish and areas } \\
\text { surrounding the study } \\
\text { area }\end{array}$} \\
\hline & & & Dwellers & \\
\hline & \multirow{3}{*}{$\begin{array}{l}\text { REAL ESTATE } \\
\text { MARKET }\end{array}$} & \multirow{2}{*}{$\begin{array}{l}\text { Buying and } \\
\text { selling market }\end{array}$} & Number of houses in terms of offer & \multirow{3}{*}{ Parish } \\
\hline & & & Cost of houses in terms of offer $€ / \mathrm{m}^{2}$ & \\
\hline & & Renting market & $\begin{array}{l}\text { Number of houses in terms of offer } \\
\text { Cost of houses in terms of offer } € / \mathrm{m}^{2}\end{array}$ & \\
\hline
\end{tabular}

Table 6: Parameters considered for the economic values associated to the project 


\begin{tabular}{|c|c|c|c|}
\hline NUMBER & WORKING HOURS & ASSOCIATED ACTIVITY & DESIGNATION OF THE ACTIVITY \\
\hline 7 & Full-time - 40h/week & Cultural facility (Public) & Culture department (Municipality) \\
\hline $1(*)$ & Part-time - 16h/week & Cultural facility (Public) & Tourism interactive shop (Municipality) \\
\hline $4(*)$ & Full-time - 40h/week & Educational facility (Public) & $\begin{array}{c}\text { Environmental education centre } \\
\text { (Municipality) }\end{array}$ \\
\hline $6(*)$ & $\begin{array}{l}1 \text { Full-time - 40h/week } \\
5 \text { Part-time - 16h/week }\end{array}$ & Sports facility (Public) & $\begin{array}{c}\text { Gramido Nautical Centre (Sports } \\
\text { Association) }\end{array}$ \\
\hline $28(*)$ & $\begin{array}{l}18 \text { Full-time - 40h/week } \\
10 \text { Part-time - 16h/week }\end{array}$ & Commercial unit (private) & $\begin{array}{c}\text { Restaurant and Bar at the nautical sports } \\
\text { centre }\end{array}$ \\
\hline $2(* *)$ & Part-time - 16h/week $(* *)$ & Commercial unit (private) & Cafeteria 1 \\
\hline $2(* *)$ & Part-time - 16h/week $\left(^{* *}\right)$ & Commercial unit (private) & Cafeteria 2 \\
\hline $2(* *)$ & Part-time - 16h/week $(* *)$ & Commercial unit (private) & Cafeteria 3 \\
\hline $3(* *)$ & Part-time - 16h/week $(* *)$ & Commercial unit (private) & Cafeteria 4 \\
\hline 49 & \multicolumn{3}{|c|}{ Total number of created direct job positions } \\
\hline 25 & \multicolumn{3}{|c|}{ Total number of created direct job positions - part-time } \\
\hline 24 & \multicolumn{3}{|c|}{ Total number of created direct job positions - full-time } \\
\hline 37 & \multicolumn{3}{|c|}{ Total number of created direct job positions - commercial units } \\
\hline 12 & \multicolumn{3}{|c|}{ Total number of created direct job positions - facilities } \\
\hline
\end{tabular}

Table 7: Direct job positions created at the study area

Source: Gondomar City Council (Divisão de Espaços Públicos e Dinamização); Gramido Nautical Centre (Clube Naval Infante D. Henrique - Valbom, Gondomar).

\begin{tabular}{|c|c|c|c|}
\hline NUMBER & WORKING HOURS & ASSOCIATED ACTIVITY & DESIGNATION OF THE ACTIVITY \\
\hline $7\left(^{*}\right)$ & Full-time $-40 \mathrm{~h} /$ week & Gardening (Public) & Urban maintenance (City Hall) \\
\hline $4\left(^{*}\right)$ & Full-time $-40 \mathrm{~h} /$ week & Surveillance (Public) & Urban maintenance (City Hall) \\
\hline $1\left(^{*}\right)$ & Full-time $-34 \mathrm{~h} /$ week & Cleaning (Public) & Urban maintenance (City Hall) \\
\hline 12 & Total number of created indirect job positions \\
\hline 0 & Total number of created indirect job positions - part-time \\
\hline 12 & Total number of created indirect job positions - full-time \\
\hline
\end{tabular}

Table 8: Indirect job positions created at the study area

Source: Gondomar City Council (Divisão de Espaços Públicos e Dinamização). 


\begin{tabular}{|c|c|c|c|c|}
\hline GENERAL DATA & \multicolumn{2}{|c|}{ Less busy day } & \multicolumn{2}{|c|}{ Busiest day } \\
\hline Date & \multicolumn{2}{|c|}{$08-10-2014$} & \multicolumn{2}{|c|}{$26-10-2014$} \\
\hline Meteorological conditions & \multicolumn{2}{|l|}{ Sun } & \multicolumn{2}{|l|}{ Sun } \\
\hline Temperature & \multicolumn{2}{|l|}{$28 \div \mathrm{C}$} & \multicolumn{2}{|l|}{$27^{\circ} \mathrm{C}$} \\
\hline Arrival hour & \multicolumn{2}{|l|}{15.00} & \multicolumn{2}{|l|}{15.00} \\
\hline Departure hour & \multicolumn{2}{|l|}{16.45} & \multicolumn{2}{|l|}{16.45} \\
\hline \multicolumn{5}{|l|}{ TIPIFICATION USERS } \\
\hline Total number of users & \multicolumn{2}{|l|}{123} & \multicolumn{2}{|l|}{1605} \\
\hline Number of users moving & \multicolumn{2}{|l|}{40} & \multicolumn{2}{|l|}{1216} \\
\hline $\begin{array}{l}\text { Number of users resting (bathers/commercial } \\
\text { units) }\end{array}$ & \multicolumn{2}{|l|}{71} & \multicolumn{2}{|l|}{379} \\
\hline Total number of cyclists & \multicolumn{2}{|l|}{7} & \multicolumn{2}{|l|}{10} \\
\hline Number of bathers at Ribera de Abade beach & \multicolumn{2}{|l|}{15} & \multicolumn{2}{|l|}{51} \\
\hline Number of bathers at Lavandeira beach & \multicolumn{2}{|l|}{11} & \multicolumn{2}{|l|}{28} \\
\hline Total number of bathers & \multicolumn{2}{|l|}{26} & \multicolumn{2}{|l|}{79} \\
\hline Number of users at commercial unit 1 & \multicolumn{2}{|l|}{2} & \multicolumn{2}{|l|}{29} \\
\hline Number of users at commercial unit 2 & \multicolumn{2}{|l|}{6} & \multicolumn{2}{|l|}{56} \\
\hline Number of users at commercial unit 3 & \multicolumn{2}{|l|}{8} & \multicolumn{2}{|l|}{75} \\
\hline Number of users at commercial unit 4 & 29 & & 140 & \\
\hline Total number of users at commercial units & 45 & & 300 & \\
\hline TIPIFICATION CARS & FEA (1) & DEA (1) & FEA (1) & DEA (1) \\
\hline Number of cars at the main entrance parking 1 & - & 18 & 30 & 100 \\
\hline Number of cars at entrance parking 2 & - & 3 & 2 & 10 \\
\hline Number of cars at entrance parking 3 & - & 2 & 3 & 15 \\
\hline Number of cars at entrance parking 4 & - & 12 & 35 & 40 \\
\hline Number of cars at entrance parking 5 & - & 7 & 10 & 48 \\
\hline Number of cars at the main entrance parking 6 & - & 5 & 5 & 5 \\
\hline Total number of cars & - & 47 & 85 & 218 \\
\hline $\begin{array}{l}\text { Number of arrivals and departures of cars on th } \\
15.30-15.40 \text { ) }\end{array}$ & jiest day & rking at e & cce 1 - & 40 \\
\hline
\end{tabular}

Table 9: Number of users 